\title{
White Line Managers and Black Labour: Ticking the Boxes of Decolonisation in a Teaching and Learning Unit of a 'First Class' University in South Africa
}

\section{Sieraaj Francis \\ ORCID iD: https://orcid.org/0000-0001-6012-0467}

\begin{abstract}
This paper offers an existentialist account of the writer's refusal to participate in 'decolonial pedagogical practices' as instructed by his line manager - a White woman who considers herself a liberal - within a teaching and learning unit of a 'first class' university in South Africa. The paper sets out to unpack all of the ways in which the university in question, post \#RhodesMustFall, and \#FeesMustFall positioned itself as a site of decolonisation, with its White liberal colonial staff still actively in positions of leadership continuing their reign.
\end{abstract}

Keywords: Black labour, decolonising teaching modules, teaching-andlearning, racist pedagogical practices, Coloured and Cape Malay men in education

\section{Introduction}

This paper offers an existentialist account of the writer's refusal to participate in 'decolonial pedagogical practices' as instructed by his line manager - a White woman who considers herself a liberal - within a teaching and learning unit of a 'first class' university in South Africa. The paper sets out to unpack all of the ways in which the university in question, post \#RhodesMustFall, and \#FeesMustFall positioned itself as a site of decolonisation, with its White liberal colonial staff still actively in positions of leadership continuing their reign. 
This paper offers an account of how the university continues to have colonisers steer the ebb and flow of the country's decolonisation agenda, most of whom without questioning their lived experience continue to perpetuate racism, which they claim to be against yet continue to inflict upon Black staff who now share the same pedagogical platform, albeit under their colonial leadership. This paper began as a letter to the upper management of a 'first class' university in South Africa to seek assistance in dealing with racist, colonial management practices that I, a Muslim, Black man with a racialised and ethnic Coloured and Cape Malay ${ }^{1}$ identity, had been experiencing in a teaching and learning unit at the said university. The letter described how over a period of a year, I was constructed as a 'less-than' by my White line manager and how my line manager's irrational and inappropriate verbal outbursts in a team meeting confirmed my suspicions, and thus provided the public evidence: that her construction of my presence, the one she concocted, was based on racial stereotypes and her personal racial biases of my identity, mostly drawn from a segment of the community of people from which my identity emerges who worked as gardeners and cleaners in their homes, or mechanics, without the necessary qualification who nonetheless speedily attended to their fancy cars. For the best of most of the half the year I was ignored; then later, simply as a brown body, I was roped in to assist with a teaching-and-learning tool. During the process, my White woman line manager became frustrated because I, as a Muslim man who identifies as Black, historically constructed as a Coloured man in the city of Cape Town, refused to avail my decolonisation expertise to a project that in its nature was misaligned to decolonial epistemologies and ontologies. The latter, an ethical position on my part, came as a complete shock to her.

${ }^{1}$ I use the term Cape Malay, as it situates my heritage at the Cape, which is one of a history of enslavement by the Dutch colonisers who used the term Malay (to also denote the Muslim faith) and Cape Malay to denote the history of enslaved people that were brought from Malaysia and Indonesia to the Cape. The merge of Cape Malay, and Cape Coloured has very particular stereotypes, some of which include a 'rol,' a style of walking which can be traced to the period when the inside of the sole of an enslaved man's foot was cut, when caught escaping. See Rozena Maart's, Black Consciousness and the Politics of the Flesh (2021). 
As a young working person, who obtained my undergraduate degree at the University of Pennsylvania, my presence in a centre of this kind within the broader context of this 'world-class university' with a history of White women leadership in many teaching centres, meant that her racist assumptions of my Black, Coloured and Muslim identity were the premise for her engagement with me, not my higher education at an Ivy League university in the United States of America (USA). The team I worked within, along with the predominantly White women staff members in my department, only engaged with the notion of decolonisation in a tokenistic manner - as a form of book knowledge that could be rehearsed, rattled off like a cheap and worthless poem written on a stolen piece of paper that could be inserted into the book without once engaging with the content. We are here talking about 342 years of usurpation and settler colonialism, spanning from the emergence of Jan Van Riebeeck on 6th April 1652 to 27th April 1994, when South Africa participated in the first process of one person, one vote. In this process the very colonisers were in the same room, the same building, the same university, taking the lead in my decolonisation, within education, and that of the rest of the $90 \%$ of the population of the country, while treating this process as normal, and beneficial to me. When I pointed out how the intricacies of colonialism were not dealt with by the very White women who were simply instructing on the technical aspects of the project but not looking at their own continued colonial behaviour - that this was more of an 'applied' project, and not one that showed honest engagement - I was met with a flurry of White tears, a regular practice but these days afforded a sophisticated term since the DiAngelo text White Fragility (DiAngelo 2018). First there were tears, then an accusation followed the tears, and I was told that since I did not want to assist with the said project, I was therefore, sabotaging the project. In this paper I set out three specific tasks in addressing decoloniality within this particular university system within South Africa, where my experience took place, as the example:

a) I analyse my interactions with the White woman line manager to whom I reported, the managerial practices of the department and the racialised outbursts that followed as a means to understand the dynamics of racism and coloniality within the 'Teaching-andLearning' setting, at the backdrop of the decolonial curriculum work that has been taken up in universities across South Africa; 
b) I examine how racism and coloniality continue to dominate spaces in 'post-apartheid South Africa' with a particular focus on the location within which I worked; and

c) I critique White staff members' reluctance to meaningfully engage with decoloniality and suggest that it is a danger to the progress of the decolonial project as both an epistemological and ontological endeavour in South African universities.

\section{Existentialism as a Research Method and an Approach to Addressing Racism}

In this segment, I offer a reconstruction of a dialogue that took place in my work environment as a means to engage the reader in the performative processes of race and racism. Not only are Black and Coloured people expected to perform our racialised identities, but we are expected to 'perform' in accordance with the stereotypes that White people still hold near and dear. Telling and retelling incidents of racism serve the purpose of noting the act; my concern is to show the dynamics, to set the scene, and to offer a reconstruction of the event in order for the reader to visualise it under my written guidance. I draw on Maart's 'Race and Pedagogical Practices: When Race Takes Center Stage in Philosophy’ (Maart 2014a) as a means to situate racist pedagogical practices. Dialogues presented in this paper are from different meetings and engagements that occurred over a period of six months. Whilst there was no recording of the events in question, the recollection here asserts the necessity of voice and allows for a visual enactment of a dialogue, which like many of its kind are often treated with moral indignation or sheer White liberal disbelief (Gordon 2000).

\section{Background}

I started working in the teaching and learning unit of a 'first class' university in South Africa in May 2018 as an Online Learning Designer. The recruitment process in which I participated, sought to simultaneously appoint three people into identical posts. I, along with a White Afrikaner woman, and a fair-skinned Muslim woman were successful in this application and were employed within the same job description. Given the history of South Africa, it is important to 


\section{Sieraaj Francis}

note that racialised identities are noteworthy not only in the decolonial era (but because they often inform the reasons for our hire, or not) and shall be unpacked later in the paper.

Once I began working in this post, I was given different work tasks to the two women who were appointed, both of whom I note above. I was put in an assistant role on multiple projects, with no lead role on projects of my own while the two women who were appointed in the same position, were appointed in leadership roles of two projects each. The timing of the projects could not be used as a justification, as I had been the second of the three to start working in this role, which meant that the opportunity to work and lead the projects was available when I started. In my assistant and support role on these projects, I was mainly brought in to fix things and do menial tasks, in other words as a racialised, gendered, Black man, of Coloured ethnicity, and of Muslim faith, who was now 'playing' the handy man role to the White woman line manager. The White woman line manager placed us in these positions based on her racial bias of what she deemed appropriate levels of work to match our physical appearance, with the stereotypes she held. On one of these projects, I had to intervene in the design of a promotional video which I watched out of curiosity - a process that I was not included in nor encouraged to view as part of the team but which I undertook of my own accord because the promotional video itself was racist in the way it positioned Black people as recipients of White saviourship. In other words, with an overwhelming sense of how White researchers believe in the need to save Black people from ourselves.

Shortly after watching the video and mindful of its severe shortcomings, I approached a co-worker, a Bikoist non-white ${ }^{2}$ (Biko 1984), the project leader, to explain my position to her and offer my critique of this flawed and offensive process. After explaining what was wrong with it in great detail, the Bikoist non-white project leader was still unconvinced of my argument, but thought that since I felt strongly about it, she would take my concerns to the client. The concerns around the racist nature of the video were then offered to the client: a team consisting of three White men and one White woman, who in turn agreed with my critique of the viewing and noted that it was racist. After the team of White people accepted that it was racist, the project leader then

2 According to Biko, non-whites (Biko's spelling) are people who aspire to Whiteness, yet their pigmentation makes this aspiration unattainable (Biko 1984). 
accepted this as a legitimate fact and asked me how I would fix it. Again, I explained what the problem was in great detail, but I refused to provide the sought-after solution. If one follows the thinking and the string of actions that connect the thinking towards meeting the final objective, in other words colonial thinking, managing the colonised in order to obtain a decolonial outcome - it is clear that the appearance of a finished product was the focus, not the process or manner in which the product was produced. Thus, the focus was not on the actions of the producers or the racism that was so evident among the manager and her underlings as agents of racism who took their knowledge to the product, under her colonial guidance, and produced it precisely as indicative of their unexamined, unchallenged, colonial lives.

There was no discussion as to what the product said about the team or that as team members there needed to be a discussion of how we put ourselves into the work we do in developing decolonial teaching-and-learning products - unpacking forms of privilege, forms of complicity that women who identify as Coloured within the team were so diligent in performing as part of their histories of internalised racism, some of which speak directly to seeking affinity with their White colonisers. The decolonial backdrop woven into the existing transformation agenda, was as much a part of our everyday lives as it was on the agenda of the university where we worked and yet there was no discussion of either. After the revelation by the client of the product as racist, there was silence. The silence was followed by a 'top to bottom' accusation, instruction, and exertion of colonial governance to again 'take charge'. As such, the scrambling to 'fix the problem' began. At South African higher education institutions, there's an expectation to be silent about racism, as it helps White people keep their status as the benefactor of racism intact, it protects White people from the 'stigma' of racism, the silence prevents colonised people from being alienated from White staff and protects dominant White discourses (Costandius et al. 2018; Jawitz 2016).

The silence I speak of here, allows the staff to protect themselves from having to acknowledge, interrogate and disrupt their own racist beliefs and practices. My line manager approached me shortly after the notification of the clients' dissatisfaction and the reason for the dissatisfaction, for which I was expected to be grateful. Shouldn't any Black man who is sought out by a White woman in the workplace where she is still 'the boss', the proverbial South African 'White madam', be grateful that she has called upon him? The Coloured labourer who was called upon to play 'Mister fix-it' was now called 


\section{Sieraaj Francis}

upon to draw on his Black, and Coloured experience to fix the racism, other people's racism, her racism! The realisation that both my university education, and my lived experience, provided the best vision to include and bring insight into other people's projects, because of my 'sensitivities', was in itself a racist way to erase my Coloured, Muslim, Black, masculine presence. Instead, without having to verbalise it, my line manager constructed my presence as the Coloured, Muslim, Black man, who was sensitive enough, quiet enough, not to make her feel uncomfortable, and therefore, in using the popular word 'sensitivities' as part of a process of developing decolonial tools, she sought me out in the process of her failure. She had a sudden realisation that I must know enough about racism because she overlooked me, she tried to erase me, she ignored my university education and training, and then I surprised her: I can speak! I was therefore part of her 'second-look' not at herself, but at what she had tried to invisibilise and now had to draw in, on demand, to get the product she was incapable of producing. Within the unit I worked, the word 'sensitivities' acted as a pseudonym for someone who survived racism and still experienced it, and who was wise enough not to offend the settler colonial line manager with his experience of her racism so that she could silently use it to her benefit and the benefit of the institution. The notion of the silence of racism, and the sacrifice with which silence is met, speaks volumes on what White settler colonials still expect from Black and Coloured peoples. This gross and perverse expectation of complicity exercised by both White and non-White staff (the latter is asserted with intent, as it evokes the apartheid framing of a person who situates their identity at the backdrop of the White experience who as Biko notes, is happy to be the non-White for they are not Black) is a form of complicity in the resistance to decolonisation and it is a form 'of violence against decolonisation' and those who were affected by the racism and coloniality in the departed who need advocates (Pillay 2015).

Again, as on previous occasions, I was not given the same level of responsibility as learning designers, my colleagues so to speak, who behaved with complete assurance that they could use my Blackness and my experience of racism without alluding to it, which served them and not me. My experience of racism, my endurance of it, the meaning I made of it, the understanding I developed of its operation - these components of how racism functioned was my existential experience, for which I was not hired. Nowhere in my job description, that I shared with the White Afrikaner woman and the fair-skinned Muslim woman, was there any mention that racism specific to my experience 
would be the premise for my participation in producing a teaching-andlearning product as part of the decolonial education agenda. My Black labour was now being sought, because as the ignored, racialised Coloured Muslim boy, not man, doing menial jobs, surely, I must know how to fix racism! Surely, I, the person who was ignored, whose expertise was not relied upon must know how racism works and since I have fixed it my whole life, I must know how to fix it now at a 'first class university' in South Africa. There is something in the way that White women line managers within the unit seem to ask Black people, who they know experience racism, for our experience of their racism without having to say it (Cardinal 1983). However, they ask us not to fix the root of their racism, but to remain silent about it. Rather, we are expected to fix the mess created from their racism. Then, as part of their 'managerial' practice, they call upon our labour as Coloured and Black men and women, to fix the mess they created, and for which their lack of education on the subject never seem to render them underqualified or unqualified - they still expect to instruct, teach, design, lead and govern, and be remunerated at the highest level that their racialised Whiteness permits. In her paper, 'Race and Pedagogical Practices: When Race Takes Center Stage in Philosophy', Maart asks the question of what happens when race is central to the production of knowledge. She notes,

... when one situates race within the construction and the production of knowledge that one believes it ought to be there; when one presents it in the presence of White scholars for whom the process is foreign, alien, or intimidating, one is placing them in positions of alibis, witnesses to their own demise, without their consent (Maart 2014a: 10).

Below are three interactions with my line manager during which I, after being overlooked and undermined in my role in the team over the first six months, decided to speak up and question my manager about her practices and my role in the team, and thus, forcing my line manager to confront her own racism.

\section{Mid-year Performance Review}

After six months in support roles on a project, I sat down with my line manager for my midterm job review to see how I was meeting my Key Performance 


\section{Sieraaj Francis}

Indicators [KPIs], which I was achieving differently to my peers in the same post because we were assigned different levels of responsibility in our work. I have reconstructed this meeting based on my recollections. I situate it here, in order to insert my voice in this paper, and my Coloured and Muslim presence that had been denied and as such to show the escalation of events. I assert the existentialist method of engagement, as part of my approach to research and writing, using these very acts, to produce knowledge. The meeting, as reconstructed, went as follows:

White woman line manager: Hi Sieraaj, thanks for meeting with me. My first question for you is to ask you how you would rate your performance?

Sieraaj: Hi I actually wanted to ask you that question. I think I have been performing well in my tasks that I have been assigned. I have been doing quality work, I have done the work on time and I think all of the lead designers that I have supported have been happy with my work. But I wanted to know how you think I have been doing. I get the feeling that you may not be happy with my work. I have asked you before about giving me the same level of responsibility as [same post person 1] and [same post person 2] and make me a lead on a project, but I still haven't had the opportunity. Is there something I am doing wrong? What do I need to improve on?

White woman line manager: Well Sieraaj, I think you are a very competent person. I just think you need a little bit more experience before you can lead a project.

Sieraaj: I don't understand. Do you think that I am competent enough to lead a project?

White woman line manager: I think you are very competent. I just think you need more experience.

Sieraaj: I do not understand. If I am competent, then I should be trusted with the responsibility. If I am not competent, then I should not. If I am too inexperienced, it should mean that I do not have certain skills. 
Experience should translate into skill. So, what do I need to learn? Where can I improve?

White woman line manager: Well I think you need to show more initiative.

Sieraaj: But I think I have shown initiative. I started the conversations around roles and responsibilities and set up the meetings and facilitated the discussions and then you put [another White woman in my position] in charge of the initiative.

White woman line manager: Because it was a good idea, Sieraaj. But when I asked who wanted to take the idea forward, she volunteered.

Sieraaj: Maybe that's a cultural difference. Because I see it as when an idea comes forward that you either give it to the person who suggested it or to the person who is most competent, not just to whoever comes forward and volunteers.

White woman line manager: Maybe it is a cultural difference. I am trying to be fair and give everyone a chance to do what they want to do. I want to be a democratic leader I don't want to just tell people what they need to do.

Sieraaj: Well, I don't want to do volunteer work here. I want to be recognised for my contribution and given responsibilities based on merit.

White woman line manager: Then you need to show more initiative and take-up those roles.

Sieraaj: Well, I have been thinking of an idea to make a collection of videos for the lecturers that we work with, to show them what is expected of them at each phase of development for online courses. Maybe I can work on that. So that when they come and see us, they know exactly what to do.

White woman line manager: We already have something similar in 
place and we are bringing in [White man junior designer] after the holidays to lead that project.

Listening to my line manager talk about wanting to be a democratic leader made me realise how out of touch she really was. In the new South Africa, post-1994, she had no qualms reminding me that democracy was still in her favour, not mine. I left the meeting feeling very confused about my perceived competencies and what I needed to improve on in order to be considered for leadership roles. This also deeply concerned me because White man (hereafter noted as White man junior designer) was appointed on a year contract to do this work, without going through the process of a selection committee. These are the acts of White privilege that go unnoticed by White staff members as it is part of their day-to-day life; there was not even a question that the hiring did not follow university protocol. What was also concerning was that White man junior designer was an unsuccessful candidate in the recruitment process for my position and was now hired to lead a project while I, who was appointed by the selection committee, was made to assist others and to work in subordinate roles. It is also important to note, that during this time, two White freelance learning designers were also appointed to lead the development of online courses, while I was still acting in a support role, to a different freelancer, I might add. These appointment strategies and practices undermine the transformation goals of the institution. These underhanded acts made me feel that my appointment was a tokenised one to meet transformation numbers and to ensure that my White colleagues do not offend anyone by their lack of race consciousness, particularly their lack of an understanding of their own White privilege. This communicated the false belief that White people are superior in the ability to lead the course design process and Black people are only good at understanding 'Black experience', such as being easily offended because we are, allegedly, 'too sensitive'. Following that meeting, the nature of my work continued unchanged and I was still brought onto projects in a support role doing mostly menial tasks.

\section{Meeting about Assessments}

In a meeting with the project team of a particular Massive Open Online Course (MOOC), my line manager was trying to bring me on board to support the project because it had been running behind. After more than an hour of 
discussing the progress of the meeting, my line manager and the project leader, a Coloured woman, starts discussing how I can get involved.

White woman line manager: So, [Coloured woman project leader], how can Sieraaj help you, because we need to finish this up?

Coloured woman project leader: Well, on this section, it is only about getting the content filmed and finding the right people which I am working on. Then we also need the multiple-choice questions written and the subtitles checked which is grunt work, which I am sure Sieraaj does not want to do. We can get the Course Mentor to do it.

White woman line manager: I am a little concerned now, because we need to finish this work and I am looking for ways that Sieraaj can help and I have called him into this meeting and now you're saying that you don't need his help.

Coloured woman project leader: I do not see work that will be worth his time on this section.

White woman line manager: The next section will have to be released with this one. Since the main component is the big project that the student needs to do, can't Sieraaj work on that?

Coloured woman project leader: It is a small section, and it is dependent on this section, but I can work with him on it if he wants to.

White woman line manager: You see Sieraaj, this section mainly involves a project that students need to do. Some parts will depend on how we finish the first section, but we need to get started on this second section as well. Do you think you will be able to design the project? I know it is messy, but we need your help in getting it done. Otherwise, we can put you on another project. What do you think?

Sieraaj: This does look a little messy and it does look like [Coloured woman project leader] has a handle on it. Maybe we can just let her finish it. I am not sure if she wants help. I am going to have to 
familiarise myself with all parts of this course before designing this project, it might take longer than if [Coloured woman project leader] were to do it herself. If I say no to this work, what other projects are there to put me on?

White woman line manager: I do not know about other projects, Sieraaj we will have to see. So, what do you think? Can you do this work?

White man senior designer: You see Sieraaj, the project that students do on this section should really be a capstone that demonstrates the learning across all the other sections. The main part being this project that you need to design. The project ...

Sieraaj: [White man senior designer], I fully understand the task!

Annoyed at everyone in the meeting and feeling like my value to the team and role on the team wasn't fully understood, I sat in silence for the rest of the meeting. I was very annoyed that my ability was being questioned and that I was brought into a meeting with no clear purpose. I was also annoyed by the level of pretence put forward by my line manager, suggesting that I have the option to decline this work when she clearly has not thought of what my options are in terms of work scope. My role on the team did not seem clear and I felt like I was 'just there'. The following day I approached my line manager to tell her that I felt disrespected and insulted because my skills and time were undermined. This is how the meeting transpired:

Sieraaj: Hi [White woman line manager], I just wanted to come around and say that I was really not happy with the way that the meeting went yesterday.

White woman line manager: (sigh) Yes, [Coloured woman project leader] and I also are not happy about it. I was a little annoyed that [Coloured woman project leader] did not have a role for you after I told her that I was inviting you to this meeting to assist her with this project.

Sieraaj: Yes, it was very embarrassing for me to have been the topic of discussion in the meeting without really being brought into the 
meeting. I think it would have really saved me a lot of time if you two had discussed my role before bringing me into the meeting. It really made me question my purpose on the team. Then, you decide that there is possible work for me to do and then you question my ability to do it. The White man senior designer explaining the task over and over to me was even more insulting. I have lots of experience designing assessments. As a teacher, I designed my own exams and tasks all the time. I was a curriculum developer for a mathematics competition network where I wrote competition questions, and I was the assessment advisor for a digital literacy learning guide developed in this department. So, I can design assessments.

White woman line manager: Then why did not you just say so, Sieraaj!

Sieraaj: Because it is on my CV!

White woman line manager: But then why did you not just say you will do the work?

Sieraaj: Because it was unclear what you wanted me to do. I understand the task, but I was not sure if you and [Coloured woman team leader] were finished negotiating my role yet or if you have fully worked it out.

White woman line manager: Why don't you talk to her about it. She is feeling upset too. I just wanted to know if this project is something you are interested in doing. The two of you can figure out a way of working together on the project. Speak to her because she isn't happy about the meeting either.

This follow up meeting with my White woman line manager left me feeling deeply concerned, insulted and frustrated. Firstly, I thought it was entirely unfair for me to have to present my $\mathrm{CV}$ for tasks on projects that were in line with my job description as if I had to re-interview for my job on a daily basis. Secondly, if my line manager did not know what experience I noted on my CV, yet would not give me the same level of work given to others appointed in the same post that I was appointed to, with the same job description, by the same 


\section{Sieraaj Francis}

selection committee, because of my alleged lack of experience, then what was she basing my lack of experience on? If it is not the experience listed on my $\mathrm{CV}$, then it had to be on what she gazed at, took in and racialised: that is, my physical appearance, my racialised identity, my cultural identity as someone who is Cape Malay from the Cape Flats. This led me to become more wary of her racial biases as I believe they affected her managerial performance. What was further humiliating, was being insulted by the lack of regard shown towards me, having to explain to someone how you have been insulted and then being asked how to make it better. It was at that moment that I had become increasingly convinced that I had to speak up. I was further insulted later during the day by the Coloured woman team leader who told me that I 'need to smile when people give you [me] grunt work' and that the anger on my face makes me unapproachable and 'unprofessional'.

\section{The Racist Online Learning Guide}

On 8th April 2019, during a team meeting there was a particular incident that confirmed all of my thoughts, feelings and discomfort of the underlying racist attitudes within the department. There had been a tension building up within the project that the White man junior designer was brought in to lead, where the decolonisation section was not progressing well and there were very few resources on which he could draw. The latter speaks to one of the reasons for an overall lack of expertise on decolonisation in the department and a lack of projects committed to it. This made the inclusion of decolonisation tokenistic. It seemed odd to me that while we have very few projects dedicated to producing decolonial knowledge, we still decided to include it in a public guide that would be accessible on our website. Previously, on 18th February 2019, during a team meeting, the White women leadership said that they decided to 'rename' the section on transformation to a section on decolonisation. When I asked why the project members, the White woman line manager, the White man senior designer and the White man junior designer made this change, the White man senior designer responded that that is the terminology that people recognise now and that is what will attract people's attention to the guide. I then responded that they should not use 'decolonisation' just to attract attention, but they need to be committed to the substance of the decolonisation project. My white woman line manager then jumped to his defence, saying that he did not mean it that way and that they are committed. The White man junior 
designer then said he needed to consult with other people around decolonisation and accessibility for the guide. I was informed that they would consult the other two people appointed in my position on accessibility. I said that the White man junior designer can consult with myself or another colleague of ours in the department, who had been doing decolonial work across the campus, if he needed to. After that he did not really consult any of us on the matter of decolonisation; he only came to my office to ask me to point him to literature that he could consult and then I pointed him to an institutional report that another colleague had worked on and mentioned some scholars whose work might be useful. He left and worked on it by himself.

On 8th April 2019, in the team meeting, my line manager said that she was unhappy with the decolonisation section of the guide. She asked me to contribute to the section. I responded that a section on decolonisation for an online learning practice guide cannot be written on its own as decolonisation is not only an epistemic project but an ontological one as well and if the ontology of the whole guide does not match the decolonisation section then it defeats the purpose. I continued by noting that the decolonisation lens needs to run through the whole guide. My line manager's response was that it was too late to do this, as the guide needed to be completed within a short period of time. I responded by telling her that she should then exclude the section. She was not pleased with this response, saying it was an important section which needed to be there. I responded by asking her why it was so important, noting that if it was important, she would have asked me in the initial stages of the project to offer my 'decolonisation lens' to the guide and not at such a late stage. Her response was: 'It's fine. We will just make our own racist guide now and then you can make whatever guide you want later'. I felt those words deeply within my body; her words had sunk lower than I could ever communicate. I left the room immediately, leaving my laptop behind, taking only my drinking glass, thinking if I am out of line for leaving the meeting at least I can say I needed water. I went to the water cooler, drank water and knelt next to it trying to make sense of what had just happened and thought about how to respond to the situation. Some colleagues asked if I was okay and another colleague noted that I should go downstairs with him, which I did. The meeting continued without me. No one else left the room and it continued as per 'normal', with my line manager saying that it was 'unfortunate' that I had to leave when it came to a line item that I had to report on.

I returned to meeting room once the meeting was finished to collect 


\section{Sieraaj Francis}

my laptop and my line manager was still sitting there. Without really looking at me, a tactic I have come to understand as the depersonalisation of her racism, she noted: 'I suppose we have to talk about what happened, if you're not too upset'. She informed me that she did not understand what I was asking of them. She reiterated why she had asked me to point out how the document was not compatible with a decolonial lens and thought that at least I would offer a critique. I pointed out that while the guide was an online learning guide, it never once mentioned the word student. The guide rather spoke of users and audiences, which I noted was a neo-liberal approach to education that views educational practices in terms of a market and the student as a consumer. In my view such an approach does not recognise the student as an agent in the teaching-learning process and it undermines the student's ability to contribute meaningfully to their own learning. I also made a point of telling her that they should then change the title from being a learning guide to a teaching guide as the student was invisible in the process and it was aimed at those who were teaching rather than those who were learning. Her reply was that she never thought of it that way. I was shocked that a leader of online learning at such a 'world-class' institution did not think that there were people learning whose experience as learners are affected by the work that she does. I responded by telling her that the suggestions I have made were only small, superficial changes (after a quick glance at the guide) and only speaks to the language used which illuminates her underlying assumptions about students, and that a proper critique would have to dive even deeper. The same line manager was suddenly full of praise of my analytical skills and asked me to do a full critique of the guide so that they could use it.

By making menial comments, I suddenly became a critical race theorist that she had invisibilised and realising the error in her judgement, behaved towards me as though I needed to be grateful that she saw me - as human, as a human capable of critical thought. I felt insulted that I was asked to do this kind of labour on a project that I was, apparently not experienced enough to lead. Again, I was too inexperienced to lead a project but competent enough to save the project from the leaders. I informed her that she and her team needed to go and engage properly with it. As though oblivious to my remarks, she proceeded to ask me if I would not still consider writing a critique of the guide. I explained to her that she was putting me in a very difficult, unfair, unethical position whereby if I am made responsible for this aspect of the guide and if I do contribute to the guide, then I am complicit in allowing 
the racist and colonial ontologies in the department that produce this kind of work to remain uninterrogated; if I do not contribute to the guide then I am complicit for allowing racialised and colonial ontologies that exist in the department to exist in the guide. I made a point, again, of letting her know that it was unfair to put that decision and labour on me at this stage of the project. Affirming my position, she said she understood and then asked me if I can at least point her to sections in another report on decolonisation from the institution that they could use. Frustrated and tired of the argument I said that I would think about it. I left the room in shock.

I was shocked that a manager could verbalise such sentiments that promote racism: that without the assistance of my Black mind and Black racialised body, that she as line manager is admitting that her Whiteness would continue to produce racist guides. Not only is it an acceptance of racist practice, but it also puts the burden on me as a Black worker to deracialise her work as I have done before, which is a labour that does not fall onto anyone else with the same job description. It also means that White line managers do not have to take responsibility for their racist practices nor interrogate their own epistemology, ontology, and use of power. The burden falls on me, the 'inexperienced', yet competent (upon desperation in a process of discovery) when needed, Coloured, Cape Malay man. I have tried teaching my line manager in conversations, but it is very labour intensive and time consuming. My line manager has told me, 'Sieraaj, I find you frustrating, but at the same time, I learn so much from you and you give me so much to think about'. However, it is not in my KPIs to do this work, and while doing this teaching might improve things for her as a White woman and everyone else she believes my insights have educated in the workplace, ultimately it would mean I am unsuccessful in my own work. The expected double labour was exhausting, especially as I was the only one on the team expected to do it.

\section{Colonial Plantations cannot Bear the Fruits of Decolonial Work}

The reason why I was the only one who was expected to do this labour in the team lies in the complexity of the Coloured identity and how it is has been constructed historically during the colonial period in South Africa, the apartheid period, particularly in Cape Town, and the meaning it carries today in the post-apartheid era. The term 'Coloured' was an apartheid construction 


\section{Sieraaj Francis}

to describe 'mixed-race' people: those who did not fit into the White, African, or Asian racial categories (Petrus \& Isaacs-Martin 2012). The creation of the Coloured classification was an attempt 'to create a homogeneous racial and ethnic 'nation' out of a heterogeneous group of people' (Petrus \& Isaacs-Martin 2012: 93), although the absurdity of this attempt was exposed when the government broke this category further into subdivisions, including Malays, Griquas, and others. The heterogeneity of the Coloured identity has its roots in the colonial period of South Africa, following illegal, unlawful, uninvited entry, known as usurpation, when the European settlers and their enslaved populations entered Cape Town and made contact with the Khoisan people (Maart 2014b; Petrus \& Isaacs-Martin 2012). The Coloured identity was used to describe people who were considered 'mixed-race', following the 'miscegenation not only between the colonists and the indigenous Khoisan, but also between these groups and the slave populations emanating from the East'. Since those colonial times, the Coloured population formed an 'intermediate' stratum' between the colonists and the oppressed African population in South Africa, receiving privileges that were not extended to the African population (Petrus \& Isaacs-Martin 2012: 92). In addition, it is also important to note that one cannot afford the notion of privilege to a population group that came into being at the Cape through a process of enslavement; the term privilege is therefore understood within the context of the legal construction of race classification in South Africa and the divide and conquer strategies employed by the colonial and apartheid regimes (Maart 2021).

Even within the mixed-race Coloured community, those "who phenotypically resembled White Europeans enjoyed privileges that were denied to those who were phenotypically darker' (Petrus \& Isaacs-Martin 2012). This resulted in an inferiority complex where Coloured people felt inferior to the White Europeans, and even created platforms for internalised racism within the Coloured community where discrimination against each other and darker-skinned Coloured people further developed into a broad range of inferiority complexes. The above noted complexes played itself out in many different ways during apartheid, where those constructed as Coloured received less privileges and freedoms than White people, but more than African people Those who believed that they could pass for White, applied for reclassification from Coloured to White, resulting in the splitting of families and communities. Not only were there divisions within the Coloured community based on phenotype but also political and cultural divisions. On the one hand, those who 
were phenotypically similar to the Europeans assimilated into the White group to gain more privileges, as well and adopt the language of the coloniser (Petrus \& Isaacs-Martin, 2012). These particular Coloured people denied their histories of enslavement in favour of White acceptance and rejected their Khoisan, Asian and African cultures, viewing them as inferior. The culmination of these acts can be described as part of internalised racism, where some Coloured people believe 'White is right' (Petrus \& Isaacs-Martin 2012: 99). The latter was further demonstrated at the fall of apartheid, during the first 'one-person, one vote' elections in South Africa, where it was noted that many Coloured people still voted for the National Party (NP), the very same White party who oppressed them during apartheid. This trend still exists today, where the Western Cape, which is a province in which the majority of people are from the Coloured community, is the only province where the Democratic Alliance (DA) - a historically White party - won the majority vote. All the provinces, except for the Western Cape, elected the African National Congress (ANC) to steer the political leadership of the country. We can see from this and many examples currently, how many Coloured people accept the European and White people as superior and aspire to Whiteness and White culture. Those with proximity to Whiteness leveraged it to gain privileges and opportunities that would place them above the self-hatred of their own Blackness. This colonial construction still exists and is evidenced by the race politics of the higher education institution within which I worked, where Coloureds were 'blind' to the racism inflicted upon them and around them and did not want to speak up, which I witnessed first-hand, as they did not want to upset the White boss in fear of losing the privileges they believed were granted because of their affinity - whether true or not - to White culture and White identity.

When I walked out of the team meeting, no one else left, even though the racism, while directed at me, clearly affects everyone. We had a conversation among ourselves as the Coloured staff at a particular time in my experience as a worker, whereby several of us acknowledged our slave histories, noting how some Coloured people aspire to Whiteness in order to acquire privileges and how our institution is run like colonial plantations, like those set up during the colonisation of Cape Town, to turn Cape Town into a 'refreshment station' for European sailors. That particular conversation was inspired by popular music and movies such as Jay-Z's The Story of O.J. (Carter 2017) and Quentin Tarantino's Django: Unchained (Tarantino 2012), from the USA. Everyone in the conversation attempted to divide themselves, and 


\section{Sieraaj Francis}

various Coloured staff, into house $n * * * * * s$ and field $n * * * * * s$, alluding to the different roles that slaves had been assigned on plantations in the USA, where some of the slaves that the masters favoured were allowed to work in the house where the labour was much more pleasant, and others had to work in the field ${ }^{3}$.

The divisions in the department at the 'first class university' I speak of were very similar: the house $n * * * * * s$ were the ones who were favoured by the White masters and White madams; they enjoyed a certain amount of privilege and therefore, as the argument can be made, were less likely to join the antiracism fight in the department. The field $n * * * * * s$ in the department were those who had access to less privileges and did not seek favour from the masters and therefore more likely to join the fight against racism. In a little more than just a joke, I responded to the conversation when someone mentioned that I was a field $n * * * * *$ by saying 'No, I am not a field $n * * * * *$ I I am a $\mathrm{n} * * * * *$ on a horse'. This was in reference to Django who is a free man, riding onto the plantation to the amazement of both the White masters and the Black enslaved, who have never seen a Black man on a horse. It always makes me uncomfortable when South Africans, especially White and Coloured people use the n-word. There are far too many complexities around the word and around the Coloured identity which make this unacceptable. Firstly, the word has its own complexity within the US society, and the African American community. While it is pretty widely accepted that the n-word is a taboo word, the same is not the case for the word $n^{* * *} a$, which some has claimed is not linked to the

${ }^{3}$ I want to assert here, as per my discussion with the editor, that I do not use the $n$-word lightly; I use it here because it has been directed at me, used against me, when I first studied in the USA, so much so that I had to grapple with how to understand this infliction and/or whether to understand it as it had been used by Black men who sought affinity with me and saw me as part of their 'ingroup'. I also identify as a Black man and have experienced this racialisation within the USA on a daily basis. It is, as such a term that has been inflicted upon me historically both in the USA and in South Africa although with regard to the latter, in racially specific ways that speak to the history of Cape Town, the city with the largest population of previously enslaved peoples in South Africa. I return to this later in this paper. But, to note, I do quote Fanon's use of 'nigger' in his context - which is well-known - and also 'nigga' in terms of the context of this argument, and its related references, as well as the derogatory, 'niggerization'. 
same meaning as the n-word and is now a term of endearment within the African American community (Smith 2019). Most Coloured people do not know this distinction and even if they did the Coloured accent (and pronunciation) from the Cape (the community that I speak of) would make it difficult to tell which term they are using and thus difficult to establish the distinction. Secondly, Coloured people have a complex history with racism both internally and against Africans, as discussed earlier, as well as a complex relationship with the Black identity as many Coloured people do not identify as Black, therefore using the $n$-word or $n * * * a$ - would be problematic. If one has not lived or participated in a system where this racialisation took place one cannot fully understand the nuances of the term, certainly not its intent, and therefore should not participate in the misappropriation of both terms. I for one have lived in the USA and have been called both $n^{* * * * *}$ and $n^{* * *} a$, (my mother always tells everyone how shocked she was that my friends in the USA called me $n^{* * *} a$ when she visited me to attend my graduation), and even then, I was very apprehensive about using $n^{* * * a}$ myself. I use the n-word in the above passage as a recollection of being made a $n * * * * *$ in the USA and being made a $n^{* * * * *}$ at this South African university. I use it to quote from Django (the film) and to show that if I was made a $n * * * * *$ in that department then I, like Django (the free Black man), would be on my horse, a free man, ready to ride off if I needed to. I use the term $n^{* * * * * *}$ to be explicit about the direct words that were used by my colleagues and to show their acceptance and understanding of their 'niggerization' (Yancy 2005: 217). Niggerization, is described by Ossie Davis when he recalls an incident when at the age of six or seven, he is picked up by two White police officers and taken to the precinct where they proceed to make fun of him, throwing cane syrup over his head and laughing at him, turning him into their buffoon (Yancy 2005). This ritual of humiliating a Black boy, Davis calls 'niggerization'. In this ritual, Black people are constrained by White people, secluded, humiliated with the assistance of White people they can rely on to enact group dehumanisation. After they returned Davis to the street, they gave him peanut brittle as a reward for participating in this ritual. This is the trick of White Supremacist ideology, where the White gaze interpellates the Black subject as inferior, with repetition, so much so we that the internalisation forces us as Black subjects to not see ourselves outside of the internalisation of that gaze (Yancy 2005). We are made into ' $n * * * * * s$ ', slaves, the inferior object, in the White imagination and forced to partake in their rituals to make us visible in this way and to accept our 


\section{Sieraaj Francis}

inferiority as fact. Our bodies are 'given back' (Fanon 1970) or returned to us (Yancy 2005), through the imagination of the White line managers, where we are expected to look at ourselves as inferior to them. Fanon states that the Black man is made Black in relation to the White man (Fanon 1970): we are made $n * * * * *$ in relation to the White masters who have 'niggerized' us (Yancy 2005 ) in order to subjugate us, to make us accept our role as slaves so that we will accept them as our masters.

Therefore, seeing ourselves' as inferior, and seeing the White master as superior is the completion of this White supremacist task. This internalisation of our inferiority, or 'epidermalisation', as Fanon puts it, is one part of a double process; the other more primary is the economic aspect (Fanon 1970). We see this economic process in the department where workers are classified, according to a hierarchy, similar to the ones employed in a class analysis: that is, academic, and professional support/admin staff. The academic staff are mostly permanently hired, whereas the professional, support and admin staff are mostly hired on contracts. The academic staff are better remunerated, have more flexibility and autonomy around when they come to work, they get to have sabbatical leave and can study further as part of their job description, and can be promoted through an ad hominem process. In contrast, the rest of the staff have to work strict hours (sometimes having to account for every second with a digital recording system), are generally paid less, and cannot be promoted without applying for a different job at a higher level. There is a process by which a post can be regraded; those who have tried have been threatened and told they may have to reapply for the job or told that due for financial reasons their contracts may not be renewed. In both hierarchies of employees, the managers are mostly White, and if there are any Black managers, they don't manage White people.

Let me situate this matter as per my experience of it: when I was in the department (within the large centre), most Black workers had White managers, but only one White worker had a Black manager, and even then she had her own office, while her Black line manager shared an office with the other Black staff member that she managed. The physical space distribution in the office was interesting as well. As pointed out above: most White workers had their own offices, while most Black workers had to share an office. Even White man junior designer was assigned his own office when he was appointed, while the rest of us in the same position, shared an office. This job insecurity accompanied by low pay, makes Black staff more likely to play the 'good 
nigger' (Fanon 1970), because they do not want to risk upsetting their White managers and not have their contracts renewed. This fear was real, because we saw many staff who refused to participate in their 'niggerization' rituals, have their employment relationship with the department terminated at the end of their contracts, whereas the White staff and 'good niggers' (Fanon 1970), were retained from contract to contract.

Therefore, Black staff are rewarded economically for participating in their 'niggerization', because they accept their construction as inferior so that they can remain employed, and this inferiority complex develops from their acceptance of the terms of their contemporary enslavement. In turn, the White staff remain superior (or so they believe), continue in management roles with all the economic and institutional power it offers them to participate in these rituals, thus continuing to maintain their White privilege. As the inferiority complex develops within Black staff, the ideology of White supremacy is further reinforced. These master-slave relationships resemble those that operated in colonial plantations (in the USA and in South Africa), and by our own admission of being house $n * * * * * s$ or field $n * * * * * s$, we recognise that the department we work in is a 'colonial plantation'. However, when I referenced Django, saying 'No I am not a field $n^{* * * * *}$. I am a $n^{* * * * *}$ on a horse' I was expressing to the group in a sense that while we recognise that our work environment is a 'colonial plantation', we do not have to subscribe to roles of subjugation.

Our enslavement exists in our acceptance of these roles as enslaved; whether a house $n * * * * *$ or a field $n * * * * *$ we are still choosing to be enslaved and still accepting the White managers as our masters. During my employment at this 'first-class university' I made a point of rejecting this construction. What was clear was that the majority of the Coloured staff members, whether they were gaining access to privileges or not, accepted that our department and the broader university institution was a plantation community. Beckford describes a plantation community as,

Within plantation community, interpersonal relations reflect the authority structure of the plantation itself. It engenders an ethos of dependence and patronage and so deprives people of dignity, security and self-respect. And it impedes the material, social and spiritual advance. Within plantation society, the tradition, values, beliefs and attitudes which have become established as a result of long periods of 
plantation influence are, for the most part, inimical to development (Quoted in Lavia 2012:1).

Lavia further explains that:

the concept of the plantation resides within - at individual and institutional levels, and cultural practices of education are complicit in the process of reinforcing what Kamau Brathwaite called 'the inner plantation'. The 'inner plantation' therefore refers to a deeply pervasive ethos of internalised oppression (Lavia 2012: 13).

The acceptance of the enslaved role by Coloured workers (as noted above) through epidermalisation comes from this deprivation of dignity, security, and self-respect by our White colleagues, through 'niggerization', and the economic and institutional power that the White colleagues have attained from the institution. From these conversations, we can clearly see the existence of the inner plantation whereby the oppression from the White managers has been epidermalised and internalised by the said Coloured workers. Working within the plantation community impedes any decolonial development: this was my experience within the school that I worked.

In the mid-year review meeting with my line manager, when she said that I did not show initiative and that I was inexperienced, she did not see me as an Ivy League-educated man, but rather allowed her negative stereotypes of 'the Coloured' and 'The Cape Malay' to determine her engagement with me. That is, as part of the stereotype that depicts us as people 'being particularly prone to laziness, alcoholism, gangsterism, violence and drug addiction, as well as not having any recognised culture or language of their own' (Petrus \& Isaacs-Martin 2012: 88). This is how a stereotype steers into a racial trope. My White woman line manager informed me in one of our meetings that she had at one point been worried she might feel threatened by me but had experienced me to be very diplomatic. This verbal expression on her part left me flabbergasted; she, on the other hand, treated her remark as a compliment and expected me to feel flattered!

My Black body was being returned to me, again, through her racist imagination, and the verbalisation of a racial trope she had no qualms in verbalising. This meeting served as another 'niggerizing' ritual, a reminder that I am the slave, and that the 'master and madam knows what is best'. This 
reduction was not only from my White line manager, but Coloured staff members as well who, when a White staff member locked themselves out of the office, ran to find me and asked whether I could help them break into the office. This was shortly after one of them alluded to their perception that I was the 'most Coloured person in the department'. If a non-South African reader puts these two statements together: there is a White woman locked out of her office, the search for the most Coloured person begins... allow me to finish the sentence... to break into the office because this is apparently what we Coloured people do. Clearly, in their eyes, as the most Coloured person (most visibly Coloured looking as per the expected visual and physical form that Coloured identity takes for those who follow this understanding), I am, without evidence: the most threatening, the criminal, and also the laziest, etc. Again, my colleagues, the Coloured staff with whom I worked, presented me with an opportunity to be 'niggerized', hoping I would be rewarded with gratitude and elation if I unlocked the door. The falsehood of the racial trope when undertaken by one's own people, colonised Coloured people who accept the terms of colonisation, locks one into the need for approval even if it means being seen as 'the thug'. The stereotype of Coloured men as gangsters, thugs, familiar with 'breaking and entering' is an activity with which I should be familiar. In the assessment meeting, I was reduced to a Black unit of labour, where the White boss and her intermediary Coloured woman discussed what work I could do while I was in the room and argued about where to 'use me' as though I were a piece of equipment. The White man in the room assumed I was silent because I am unintelligent and repeated the explanation of the task. After being visibly frustrated and angry at the lack of a plan for me in the team and the fact that I was insulted, I was then tone-policed by the Coloured woman who labelled my expression as anger and termed it 'unprofessional'. In essence, what my Coloured woman colleague was doing was telling me that to curry favour, I have to be the 'good nigger' (Fanon 1970) and sit quietly and accept the shortcomings she has identified within herself, which she projected onto me, and toe the line, otherwise the master will be upset with me.

In the meeting about the learning guide, the 'plantation community' members all get together to discuss how the project is not progressing. The White master is now forced to acknowledge my expertise on decolonisation, but at the same time refuses to accept my role as an expert and expects me to just do as I am told so that I can help the White master in charge and White man junior designer. My line manager wanted me to complete the project 
because she, the White madam of the plantation is saying so, not listening to the actual expert knowledge that I am providing to the project since it goes against the terms of working that she had assigned to Black and Coloured people. The White leadership, with no expertise, will not go back and change the whole guide to make sure it aligns with the decolonial agenda; the decolonial agenda must fall in line with their agenda.

As discussed earlier, Maart (2014a) along with Andrews (2016), point out, that I have put the White woman line manager in a process that is foreign, alien and intimidating, and in a position where she is forced to witness her own demise. The White woman line manager erupts with anger, because I have lifted the veil and have exposed the truth: that I am not the one who is inferior, she is. And if I am not inferior, she is not superior. What I have exposed is that the whole plantation is a hallucination from the psychosis of her Whiteness, which cannot be reasoned with (Andrews 2016). Any expertise that I brought forth from that point is lost in this hallucination and cannot be rationalised in her state of psychosis. Her verbal outburst that she will 'just make a racist guide' and I can make my own guide, is an acknowledgement of the extent of her psychosis of Whiteness, her inability to reason and engage with the decolonial expertise in her presence, and her refusal to let go of the hallucination of the plantation from which she draws all of her power, and where my decolonial work has no place.

\section{Reflections upon Reflections ...}

In the analysis above of both the structures in the teaching and learning centre, as well as the interaction between my line manager and I, we see how the plantation community is constructed and how White people have established their supremacy through the ritual of 'niggerization' of Black staff. We also see how Black staff have 'epidermalised' this inferiority into accepting their plantation slave status and the White staff as their masters and madams. These acts of colonisation continue to dominate interpersonal relationships, like my relationship with my line manager, and the structural positioning of the White staff. We see how White staff side-step the selection process to undermine the transformation agenda, and we see how Black staff are overlooked for management positions. It is, therefore, evident that these White-run teaching and learning centres are incapable of responding to the call to decolonise the curriculum within higher education. The White managers and staff at these 
university academic centres are committed to the reproduction of colonial configurations of which they are the benefactors, and the Black staff are held in insecure employment positions, constructed as inferior which in time can be internalised to produce inferiority complexes.

Who then can we trust to steer the decolonial project in these academic centres? How can these projects produce decolonial outcomes and decolonial learning tools and materials? In order to develop the capacity of these centres to respond to the calls for decolonising higher education, we have to examine these processes and have an honest look at Whiteness, diagnose its psychosis, so that we can move beyond the hallucination of the plantation and develop new configurations of working. White staff must become aware of these practices and recognise their violence and harmfulness to both their Black colleagues and the projects they claim to work towards. We must develop centres and institutions of learning where Black staff are empowered, and where we can exercise our agency with the Blackness we are forced to keep dormant. It means that the master should give up their mantle and the enslaved unchain themselves. The plantation needs to be destroyed, which means that the plantation community has to be destroyed. This can only be achieved through interventions that are not led by the White management but from an external, educated, conscious, group who can identify the plantation without becoming a member of that community.

Without interventions, Whiteness and coloniality will continue to impede the development of a decolonial project in South African universities and Black staff will continue to live in violent working conditions where the only option for existence is submission as the enslaved, bound to the colonial agenda. Alternatively, the enslaved can destroy their inner plantation by refusing to participate and shield themselves from this violence. Both these choices leave 'decolonial' projects within teaching and learning centres without people who are truly committed to the decolonial project.

\section{Conclusion}

The violence that I experienced based on the racism that exists in the department (within a large school and teaching and learning centre) where I worked was enormously difficult for me to deal with. The stereotypes and complexes inherited from colonisation and apartheid have taken an emotional toll on me. But what I have learnt from this experience in terms of how 
coloniality still hold backs the work that is being done at first class universities, has been invaluable.

What is clear to see is that while previously White universities might note that decolonisation is a priority for them, they only mean it as far as the 'products' that they produce from the plantations. In other words, how things appear, not how they actually are. Like the learning guide described in this article: much like a course, or research output. But how can that soil really bear decolonial fruit when it is where the seeds of coloniality are still sown? Without a real commitment from each staff member to leave or destroy their inner plantations and without destroying the plantation community to find other ways to relate to one another, the work done in the institution can never be decolonial. In realising this, my only option was to refuse to participate. What followed from that was harassment to get me to submit and accept my place on the plantation. Facing daily harassment, I decided to resign from the institution, because they (my White line manager and her dutiful staff) could not see the plantation for what it is. The irony is that at my farewell party I was handed a farewell card by the staff with a picture of Django on it. I guess they realised that like Django, I had burnt down my inner plantation and rode my horse off into the sunset. The 'decolonial' project at that teaching and learning centre located within one of the first-class universities in South Africa, is still very much a hallucination just as the plantation of the historical South in the USA. Hallucination or not: my initiative - the one that seemed invisible to my White line manager - was part of the process of healing from the violence of the coloniser who wears sheep's clothes and poses as the decolonial technician while erasing the previously enslaved.

\section{References}

Andrews, K. 2016. The Psychosis of Whiteness: The Celluloid Hallucinations of Amazing Grace and Belle. Journal of Black Studies 47,5: 435 - 453. https://doi.org/10.1177/0021934716638802

Biko, S. 1984. The Definition of Black Consciousness. Frank Talk 1,1: 3 - 4. http://disa.ukzn.ac.za/ftfeb8416837118001001feb19845

Cardinal, M. 1983. The Words to Say It: An Autobiographical Novel. London: Women's Press.

Carter, S. 2017. The Story of O.J. (Performed by Jay-Z). On 4:44 [CD]. New 
York: Roc A-Fella Records, Def Jam Recordings.

Costandius, E., M. Blackie, I. Nell, R. Malgas, N. Alexander, E. Setati \& M.

Mckay 2018. FeesMustFall and Decolonising the Curriculum: Stellenbosch University Students' and Lecturers' Reactions. South African Journal of Higher Education 32,2. https://doi.org/10.20853/32-2$\underline{2435}$

DiAngelo, R. 2018. White Fragility: Why It's So Hard for White People to Talk about Racism. New York: Beacon Press.

Fanon, F. 1970. Black Skin, White Masks. London: Paladin.

Gordon, L.R. 2000. Existentia Africana: Understanding Africana Existential Thought. New York: Routledge.

Jawitz, J. 2016. Unearthing White Academics' Experience of Teaching in Higher Education in South Africa. Teaching in Higher Education 21,8: 948 - 961. https://doi.org/10.1080/13562517.2016.1198760

Lavia, J. 2012. Resisting the Inner Plantation: Decolonisation and the Practice of Education in the Work of Eric Williams. Postcolonial Directions in Education 1,1: 9 - 30.

Maart, R. 2014a. Race and Pedagogical Practices: When Race Takes Center Stage in Philosophy. Hypatia 29,1: 205 - 220.

https://doi.org/10.1111/hypa.12076

Maart, R. 2014b. 'Race'. In Ferrante, J., M. Seedat-Khan, Z. Jansen \& R. Smith (eds.): Sociology: A South African Perspective. South Africa: Cengage Learning.

Maart, R. 2021. Black Consciousness and the Politics of the Flesh. (Forthcoming.)

Petrus, T. \& W. Isaacs-Martin 2012. The Multiple Meanings of Coloured Identity in South Africa. Africa Insight 42,1: 87 - 102.

Pillay, S.R. 2015. Silence is Violence: (Critical) Psychology in an Era of Rhodes Must Fall and Fees Must Fall. South African Journal of Psychology 46,2: 155 - 159. https://doi.org/10.1177/0081246316636766

Smith, H.L. 2019. Has Nigga been Reappropriated as a Term of Endearment? American Speech 94,4: 420 - 477. https://doi.org/10.1215/000312837706537

Tarantino, Q. 2012. Django Unchained. (Motion picture.) Los Angeles: Columbia Pictures.

Yancy, G. 2005. Whiteness and the Return of the Black Body. The Journal of Speculative Philosophy 19,4. 
Sieraaj Francis

Sieraaj Francis

Doctoral candidate University of Cape Town

sieraaj.francis@gmail.com 